\title{
Economic Growth and Openness in Transition: A Study of Western Balkans
}

\author{
Doi:10.5901/ajis.2015.v4n1p423
}

\author{
Msc. (C) Riada Berhani \\ Epoka University, Tirana, Albania \\ rberhani10@epoka.edu.al
}

\section{Abstract}

More than two decades have passed since the collapse of communist regimes that ruled in all of the Western Balkan countries. The list of these countries includes the Republic of Albania and all countries that were part of the Former Yugoslavian Republic, except Slovenia. Only one of these countries, Croatian, reached the goal of integration to European Union. Other countries are still in their late transition journeys which aim membership to EU. This study aims to investigate the link between openness and economic growth in the Western Balkan Countries currently in transition. While the common sense indicates that openness impacts positively in the economic growth, many theoretical and empirical studies cannot fully reject or approve this statement. Even though that the majority of these studies advocate positive impact of openness in economic growth, many other prominent studies have found the opposite result or that there exist no link between these two indicators. Data set used in the empirical analysis is a panel data set for the period 2005 to 2013 from three important countries: the Republic of Albania, the Former Yugoslavian Republic of Macedonia and the Republic of Serbia. While applying a multi regression model with dependent variable the Gross Domestic Product Quarterly Growth Rate and as dependent variables the current and previous quarterly percentage change of trade volume. The main result of this study is that the openness has a significant positive impact into the economic growth of Western Balkan countries in transition.

Keywords: Openness, Economic Growth, Western Balkan

\section{Introduction}

One of the main macroeconomic goals of a country is the further rapid economic growth and development. Economic growth and development increases countries welfare though increasing standard of living, increases employment, increases tax revenues which can be used for future investments and increases the profitability of companies thus, making them bigger and more competitive in the global market. On the other hand, international trade benefits to countries and citizen due to the concept of specialization toward the sectors which country has the competitive advantages. Also, international trade makes good more reachable for many costumers which otherwise would suffer for lack of mobility.

In the last years, many countries have started to apply trade openness method in order to reach these goals. Part of the countries that started to apply this policy are also countries of Western Balkans which are inspiring for a better future by integrating into European Union. Except the Croatia, which is a member of EU, all the other WB countries are in a transition journey with the integration as its destinations. Countries which are currently (as at May 2014) in transition are the Republic of Albania (in the future Albania), the Republic of Bosnia and Herzegovina (in future Bosnia and Herzegovina), Republic of Kosovo (in the future Kosovo) Former Yugoslav Republic of Macedonia (in the future Macedonia), Republic of Montenegro (in the future Montenegro) and Republic of Serbia (in the future Serbia).

Till the late 80s and early 90s, the Western Balkan was the synonym of terrible wars and ethnic conflicts which rose again from the past after the collapse of communist regimes that ruled all the region. Only, the desire for further development and integration into EU and mainly the intervention of the western countries such as NATO during KosovoSerbian war, returned the peace after a long history of conflicts. Yet, it cannot be said that conflicts are now part of the past. However, with the collapse of communism regimes and restoration of peace in the region, the WB country have lowered their trade barrier and implemented trade openness policies in order to improve their economies.

The aim of this study is to examine the link between trade openness and economic growth in the Western Balkans countries which currently are in transition. Thus, the hypothesis investigated in the study is the one that predicts a significant positive impact of trade openness in economic growth in Western Balkan countries in transition. To examine this hypothesis, panel data multi regression analysis is used with the data of Albania, Macedonia and Serbia. Other countries needed data were absence at the time when the study was conducted, thus they could not be included in the paper. However, Albanian, Macedonian and Serbian GDP as at year 2013 respectively estimated to be US\$28.34 billion, US $\$ 22.57$ billion and US\$80.47 billion or in total US\$131.38 billion. Also their GDP annual growth rate as at year 2013 is 
respectively estimated to be $0.7,3.1$ and 2.0 percent. On the other hand, countries that are Bosnian and Herzegovina, Montenegro and Kosovo. Respectively their GDP and GDP annual growth rate are 32.16 billion and 0.8 percent, 7.43 billion and 1.5percent and 14.11 billion and 2.5 percent. The three countries included into the regression analysis represent 71 percent of the US\$185.08 billion in total GDP of the 6 countries and also the average annual GDP growth rate of these countries (1.9 percent) is very near to the average GDP of the 6 countries together which equals 1.7 percent. Thus, including just data for Albania, Macedonia and Serbia will be enough to analyze the topic in the context of Western Balkan.

This paper consists of three part. The first part analysis the theoretical framework relating with the topic. The second part reviews the most prominent work that have studied the relationship between openness and economic growth. The their part includes the regression analysis, the different needed tests to conduct it and an interpretation of the results. The study ends concluding all the finding and giving recommendation and suggestions for future studies on the link between openness and economic growth.

\section{Theoretical Approach}

Economic growth has a crucial role in economic development. Thus, the main factors that contribute in the economic growth have been an area of interest for many analyst and researchers. Improving the factors that increase the economic growth and avoiding the factors that stop or decrease the economic growth, is a way to increase the living standard. In this chapter are explained the main economic theories related with economic growth and trade.

\subsection{Mercantilism and Physocracy}

Mercantilism was the dominant economic theory in Europe from $16^{\text {th }}$ to $18^{\text {th }}$ century (LaHaye, 2008). The central belief of this theory was that the nation's wealth is based on its holdings of precious metals such as gold. According to mercantilists, trade was a 'zero sum' in which one country gained at the expense of other country (Ekelund \& Tollison, 1983). Mercantilists argued that the most powerful nation is the one with the higher amount of gold. They supported exports because they add to nation's wealth while they believed that imports reduce the nation's wealth and also increase the dependency on the trading partner. Mercantilists suggested that the government should restrict imports with tariff and other prohibition and encourage export with subsidies.

The Physiocrats were the first contestant of mercantilist theory. They were a group of French Enlightenment thinkers of the 1760s. According to them, nature is fundamental to producing wealth. They believed that the only agriculture yields a surplus. According to them the 'productive class' were the agricultural landlords while the 'sterile class' were the industrial worker, traders and merchants. Unlike the mercantilists, they considered trade as a sterile economic activity which does not produce wealth, but simply an exchange (Marx \& Engels, 1998).

At that time, French agriculture was trapped in a feudal system of the medieval time, and feudal obligation - such as the yearly labor tax farmers should pay to the state known as corvêe - was still in force. Also, the monopoly system of the merchant ruled the economy of the town and the farmers could not sell their product to the highest bidder or buy they raw material from the cheapest supplier. Physocrates condemned government intervention in the economy by saying that the economy is driven only by natural laws. Their argued that the best way for the economy to work is under 'Laissez faire' (Charbit, 2002).

\subsection{Adam Smith Theory}

Adam Smith is considered the Father of Economy (Davis et al., 2011). He defended the theory that the economy works itself, as if an 'Invisible Hand' directs it. He also criticized the commercial monopoly and the colonial system which was related with physocratic thinking (Smith, 1779). In his book 'An Inquiry into Nature and Causes of the Wealth of Nations' (1977), he wanted to examine the reasons why some countries are rich, and some are poor and also the basic factors that can contribute in an increase of the wealth of the economy. According to Smith, the wealth of the economy is not the gold as is was assumed by Mercantilists or agriculture as assumed by Physiocrats, but it is the total production (industrial and/or agricultural). Smith said that economy growth increase when the total production, income and standard of living of the nation increase. According to Smith, the total production increases when the inputs increases. The factors of production are land, labor and capital respectively owned by landowners, workers and capitalist. The Smith production functions can be expressed as: 
Equation $1 \mathrm{Y}=\mathrm{f}(\mathrm{K}, \mathrm{L}, \mathrm{N})$

Where K represents capital; $\mathrm{L}$ is the labor amount and $\mathrm{N}$ stands for land. According to Smith, output growth $\left(g_{y}\right)$, which results in the increase of overall productivity $\left(g_{f}\right)$, was determined by population growth $\left(g_{L}\right)$, investment $\left(g_{k}\right)$, and land growth $\left(g_{N}\right)$.

Equation $2 g_{Y}=a\left(g_{f}, g_{L}, g_{K}, g_{N}\right)$

In his theory, Smith argued that the population growth and investment are endogenous because population growth depends on the sustenance available to accommodate an increasing workforce and because investment is determined by the savings rate. On the other hand, Smith said that land is finite and its growth dependent on the invention and usage of new technology to conquest new land or improve the fertility of old one.

The division of labor was a crucial aspect in his theory. To explain the important of this concept, he gave his famous example of the pin factory. He said that ten people working separately can product 20 pins each in day or 200 in total. While he argued that in the modern (for Smith) pin factory with the division of labor and machine to work with the same 10 people can produce forty-eight thousand in a day. This increase of productivity was the reason behind the belief of Smith that an increase in the division of labor contributes in an increase of economy of growth. According to Smith, division of labor increase productivity for three reasons:

1. Time savings. Due to a reduction of set-up cost because the workers do not have to move from one task to another task.

2. Dexterity and education. Smith argued that workers who are specialized in a special task learn the best way to do that task by giving rise to the notion of economic if scale.

3. Invention of machines is the most important reason behind the increase of productivity. As Smith said that the specialized workers find ways to do the work with less labor and, so the number of the inventions for common worker increases. Even more important for Smith is the ingenuity of the makers of the machines.

In his book trade is the power of exchanging that give occasion to the division of labor (Smith WON I.3.1). Thus, an increase of trade increase the division of labor consequently increasing productivity and economic growth. Smith suggested that the way to extend trade are larger markets. He argued that the division of labor is limited by the extent of the market and larger market increases the incentive to specialize and to invest in machines (new technology). Also, Smith said that in order to have a larger market there should exist trust and good government, free trade, appropriate geography and natural liberty.

Moreover, Smith said that capital accumulation can increase division of labor. In order to employ the labor in the factory and to buy the machines there must be previous accumulation and savings. Smith argued that labor can be subdivided more in proportion of a stock accumulation. In order to generate more output, self-interest will encourage capitalist to divide labor because of increasing return of scale. Also, Smith indicated that only investment generate capital and only capitalist class invest because workers in the long run receive subsistence wages which are the minimum necessary wage to survive thus, cannot safe while agricultural landowners only consume and do not save.

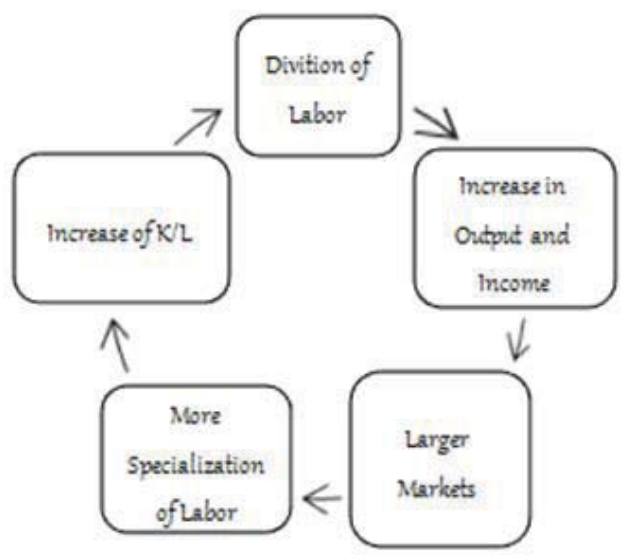

Figure 1: The Virtuous Cycle of Adam Smith

The Smith Virtuous Cycle explains how the division of labor leads to higher productivity. Capital accumulation increase with the slope capital over land (K/L). Higher slope means higher productivity and consequently higher incomes which leads to an increase in demands and larger markets. As mentioned above larger markets lead to an increase in specialization of labor and the division of labor increases thus, productivity increases. 
Furthermore, Smith promoted the free trade in his Theory of Absolute Advantage. He argued that trade is a 'winwin' game, and not a 'zero sum' game as mercantilists believed. According to Smith a nation has an absolute advantage when it has a higher amount of the output per worker in one hour or when the amount of hours it takes a worker to produce a unit of output is less. He said that a nation should export those goods that is better in producing and should import those good that other nations are better at producing.

However, Smith didn't see economic growth as infinitely rising. Due to the competition labor and capital accumulation increase thus the employment and total wage also increase. Consequently, profit decrease, investments and growth level fall and eventually rate of economic growth becomes zero. Smith created a ceiling and a floor limit at the stationary state where the capital accumulation and population growth are equal to zero.

\subsection{David Ricardo and Thomas Malthus Theories}

David Ricardo is an early $19^{\text {th }}$ century economist and author of 'On the Principle of Political Economics and Taxation' (1817). Ricardo was a follower of Adam Smith and accepted almost all the Smith model and his book is mainly a commentary of Smith book (Davis et al., 2011). His book concludes that the rent of lands will increase as the population increase. He also introduced the theory of comparative advantage which, in contrary to absolute advantages theory of Smith, indicates that all nations can benefit from free trade (Roberts, 2003). According to Ricardo, one country exports the goods which produces at a lower cost relative to other countries and import those goods that have a production cost relative higher than in other countries.

David Ricardo modified the Smith's growth model by including the concept of diminishing returns to land in the stationary state. The concept of the diminishing return states that if a unit is added to one of the factors of production while the rest is kept constant, the amount output per unit will decrease and of eventually the overall output will reach a level of zero (Samuelson \& Nordhaus, 2001). Similarly to Smith, Ricardo argued that the land is finite (Ricardo, Chapter 6 , On Profits, 1817). Relying on the Malthusian population theory, he said that, with the increase of population the demand for the good will increase and thus the existing land will be over cultivated faster than Smith predicted thus, he was pessimistic that the stationary state will come quicker (Ricardo, 1795).

According to Thomas Malthus, the population grows geometrically while the food supply grows arithmetically, thus slower than population growth. He predicted that the population would outstrip the food supply causing an increasing misery. This change in the growth ratio between population and food production would contribute in a fluctuation of per capita income. Malthus describes a vicious cycle where the increase of per capita income will result in an increase of population growth and consequently per capita income will fall to its initial level (Malthus, 1978. On the other hand, John Start Mill, the most famous Utilitarian philosopher, opposes Malthusian theory by arguing that education level will increase, and a better education will restrain population growth (Winch, 1996).

\subsection{Karl Max Theory}

Marxism is a theory based on the ideas of the philosopher Karl Marx. Marxism is known as a conflict theory because the classes of the society are in conflict with each other and Marxism states that this conflict is between the rich and the poor. Marxism theory is the opposite of Capitalist theory which according to Marxism it is an economic system based on private ownership of the means of production. Thus, according to Marxism, the Capitalism produces inequality by creating two classes the Bourgeoisie (the middle class) and the Proletariat (the working class) which are considered as the oppressed class. Karl Marx saw capitalism as a system that tries very hard to make sure that poor stays poor and rich continues to get richer (Calhoun, 2002).

Marx opposed the Smith and Ricardo's assumption that labor is endogenous with respect to wages. He argued that wages are determined by bargaining between bourgeoisie and proletariat class rather than by necessity or natural factors. Also, the process of determining the wages, he said, would be influenced by the amount of the unemployment in the economy. He also said that savings and capital accumulation depends on the profit and raw materials. Opposing Smith, he said that a declining profit rate will not decrease capital accumulation, but only would increase the incentive of capitalist to decrease wages and thus, worsening the proletariats' life (Howard \& King, 1989).

Marx also suggested that more capital intensive methods of production should be introduces over time because he believed that the profit rate will decrease in the long-term due to the rise in the organic composition of capital. According to Marx, the competition which increases wages and diminishing returns on land had less effect on the declining rate of profit (Howard \& King, 1989). 


\subsection{Harrod - Domar Model}

Harrod - Domar model tries to explain in a simple equation the relationship between savings, efficient capital productivity and economic growth. This model was independently developed by Sir Roy Harrod (1939) and Evsey Domar (1946). According to them the economic growth depend on three factors: the saving rates, the ratio of capital over output and the depreciation rate. Their model suggest that the economic growth rate depends on the savings and investments because savings make available the fund that are used for future investments.

The model made four assumptions. Firstly, savings are in propositional to income. Second, the ratio of capital over output is contending. Third, investments are allocated between increasing capital stock and depreciated capital. Forth, at the equilibrium point the desired savings equal the desired investments.

The main finding of the model is that an increase in the level of investment is the key to an economic growth. This increase in net investment would lead to more accumulation which consequently would lead to higher income and output. Thus, higher income leads to a higher level of savings.

However, the model was criticized that that it did not take into consideration other crucial factor of production such as labor. Population growth or labor force growth are not included in the economic output growth formula. Moreover, model is an extension of Keynes' economic growth model in the long run under the condition that a growing economy would lead to a full capacity and full employment. Yet, Harrod (1939) argues that there is no exact mechanism to ensure an equilibrium between the natural and warranted rate, which the latter is characteristically unstable. Domar (1946) said that his difficulty in finding an equilibrium arises due to the tendency to underinvest thus, the investment growth rate does not match the savings growth rate. Thus, it is highly possible that the warranted rate of growth $(\mathrm{s} / \mathrm{v})$ will differ from the natural rate, and consequently the full employment will not be ensured. In the absence of any mechanism which would ensure the equilibrium between these rates, economies continue to face periods of unemployment fluctuations and/or degree of capacity utilization increase or decrease.

\subsection{Solow Growth Model}

Solow model was developed by Robert Solow 1956 and explains how growth in the capital accumulation, in labor force and developments in technology interact in an economy system and how do they affect the output of a nation. It suggest that how much economic growth come from capital, labor and new technology. Until Solow Model this break in basic of the economy was never done properly before.

The model made three assumption. First, there is a constant exogenous labor force growth rate. Second, the output is a function of capital and labor. Third, there are constant return to scales and diminishing marginal return to capital. The model also stated that the macroeconomic equilibrium is when aggregate demand is equal to aggregate supply. Thus, in other words it can be translated as the equilibrium is when savings equal investment. As the result, also this model suggest that the savings rate of the economy determines the size of its capital accumulation and thus, it level of output. According to the model, an increase in the saving rate will generate a rapid economic growth out of a steady state. However, this growth is not persistent because it will eventually slow and a new steady state will be reached (Solow, 1956).

The level of capital needed to reach the new steady state in the economy is known as the Golden Rule (capital maximization rule) which is characterized by equality between steady-state growth rate of income and net marginal product of capital. This rule indicates that if the economy has a higher amount of capital that in the Golden Rule steady state, than the consumption can be increased at all points in time by reducing savings. On the other hand, if the amount of capital is lower, than the investment should increase in order to reach the Golden Rule steady state and thus, the consumption for the future generation will decrease (Swan, 1956).

Moreover, Solow Growth Model indicates that the population growth rate and technological progress are determinant of the standards of living. Accordingly, the population growth rate has a negative relation with the capital per worker and output per worker thus, higher population growth level will generate lower levels of the steady state capital per worker and output per worker. Moreover, an improvement in technology increases the efficiency of worker thus, the level of output per worker increases. According, to the Solow Growth Model, only technological improvement can generate continues increase in the standard of living and explain sustained growth (Solow, 1957).

Another key feature of the Solow model is the catch up growth which is the rate at which the poor country tries to catch up the rich country. Because of the catch up growth the Solow model predicts that there will be a convergence of living standards around the world because the poor country will eventually catch up the richer country (Raurich \& Sorolla, 2012). 


\subsection{Endogenous Growth Theory}

The neoclassical theories such as the one of the Solow Growth Model, assumes that the technology is determined by scientific processes that are separated and independent of economic forces thus, they take long run growth rate as exogenous outside the economic forces. While the endogenous growth theories by arguing that the technological progress hence the long-run growth rate, is affected by the economic factors because it is generated from innovations in form of new product or markets many of which resulted the economic activities (Romer, 1994).

Endogenous growth theory indicate that further improvement in the human capital and faster pace of innovations result in higher level of output. Moreover, according to endogenous growth theory, the knowledge is considered as a curtail determinant of economic growth. The theory predict that extra added knowledge, thus an extra investment on human capital, will generate positive externalities and spill-over effect that will develop the economy and also help the country in maintaining and increasing the competitive advantage position in the global economy (Romer, 1994).

The key difference between endogenous models and Solow model is that, they do not take into account the diminishing return to capital. Advocates of the endogenous model assumes that knowledge is a form of capital and thus they argue that it does not exhibit the diminishing return to capital. According to the endogenous models economy exhibits constant return to capital (Mankiw, 2006).

The basic endogenous model, the AK model, explains the output as a function of capital and a constant that measures the output produced for each unit of capital. While the two sector model aims to explain the long-run growth in two sectors: manufacturing firm which produces goods and services used in consumption and investment in physical capita, and universities produces knowledge which is a factor of production freely used by both sectors. In the Solow model, the savings temporarily lead to an economic growth, however according to the AK endogenous model, saving can lead to persistent growth. Moreover, according to the two-sector model the economy exhibit persistent growth and is endogenous because work at universities never stops (Mankiw, 2006).

\section{Literature Review}

So far, models give a clear picture of how, theoretically, closed economies react or not to economic incentives derived from the markets. However, to analyses the economies in the age of nowadays globalization the importance to include other elements in these models in significantly increased.

Many researchers have studied the effect of trade on economic growth and the majority of their studies indicate that the trade causes economic growth. Several important studies such as Edwards (1998), Sachs and Warner (1995) and Dollar and Kraay (2001) argued that a positive link exists between trade openness and growth. This section includes the reviews of the most prominent literature that studied this relationship. However, there are some literature indicated the non-existence of a positive correlation between openness and growth. One of the prominent critics of a strong relation between openness and growth are the studies of Lee (1993) and Rodrik (1995).

Corden (1971) argued that openness affect growth in five channels: the impact effect, the capital accumulation effect, the substitution effect, the distribution effect and the factor weight effect. The impact effect is linked to the static trade gains, and it results in an increase in the real income. The capital accumulation effect is generated from increase of real income by the impact effect which is now invested. Thus, part of the consumption is transferred to the future. The substitution effect holds only when the goods invested are import-intensive. Thus, the consumption ratio will increase due to a possible fall of price of investment goods to consumption goods. This increase will result into an increase of growth rate. The distribution effect results from the transfer of the income to the production factors that may be exported goods of the country. The factor weight effect assumes that the weighted average of capital growth and labor is the rate of output growth. Assuming that the factor of production between labour and capital of exports grows faster, an increase in exports would result in an even higher rate of growth of exports. Arguing that these effects are cumulative, Corden said that they support and increase the growth rate of open economies.

Lee (1993) found a negative relationship between openness and growth. In his study, he used an index of trade policy, which includes the black market premium and tariff average, and a measure of openness which is comprised by four elements: the land area, the distance between trade partners import tariffs and black market premium. Lee also concluded that there exist a reverse causation problem when the growth causes openness. This problem may occur in countries with high growth rate which start to liberalize their trade. This situation hampers the analysis of the effect of openness on growth.

Rodrick (1995) used a sample size of 90 countries. He also used the ratio of debt to exports, the ratio of exports to GDP, the government consumption share in GDP, the average tariff rate on import and the Sachs and Warner index. In 
his model, he founded none of these variables, except government consumption, to be significant. Thus, he concluded that no evidence exists to advocate a positive relationship between trade and growth.

According to Sachs and Warner (1995) the economies that evidences for a conditional convergence can be founded in the open economy while the closed economy tend not to converge. They also conclude that trade policy is an important factor for economic growth and convergence. In their paper, they explained that the countries with higher economic growth are those that applied market reforms. Even though that trade liberalization, they argued, is one stage of market reform process it can be use as a proxy to measure the overall process. According to them, when a country applies market reforms it joins the world market thus, in order to coup with the increased international competition efficiently, the government is force to implement changes in the reform program. In Sach and Warner model an index of five variable is used as a binary variable. According to this index the economy is an open economy if none of the following statement does exist.

- The country has a socialist economy system.

- A state monopoly on principal exports.

- Non tariff barriers rate on imports is less than $40 \%$.

- Average tariff rate is higher that $40 \%$.

- The black market exchange rate premium is higher that $20 \%$.

According to Edwards (1998) openness is a crucial factor of growth of economy. To demonstrate this importance he used the concept of productivity. In his regression model, he included nine indicators of trade openness taken from the trade startegies classification in World Development Report 1987 of the World Bank. He argued that the productivity growth is positively related with the openness because the majority if the indexes are positively correlated with the productivity growth. The nine indexes are: Sach and Warner openness index, World Development Report Orientation Index, Leamer's Openness Index, Average Black Market Premium, Average Import Tariff on Manufacture, Non Tariff Barriers Average Coverage, The Ration of Collected Trade Taxes and Wofl's Import Distortion Index

Moreover, Dollar and Kraay, 2001 model indicates that the economic growth is positively related with the openness. TheY established this relationship by using data from 68 countries and categorising them into two groups regarding the increase in the each country trade to gross domestic product (GDP). Thus they classified 24 countries whose ratio increases as globalizers during the years 1980s and 1990s and the rest as non-globalizers. According to them, the volume of trade of the globalizers has significantly change during the studied period. These countries could reduce their tariffs by 22 percent consequently doubling their GDP. On the other hand, the non-globalizers reduced their tariffs and thus, they experienced lower trade to GDP ratios. Although, they also concluded that changes in this ratio do not always illustrate change in trade patterns due to the fact that the ratio depends on initial conditions of the country than on trade policy.

Rodriguez and Rodrick (2001) also conclude that even though many studies founds a string relationship between openness and growth; the models used in these studies are econometrically misspecified. They argued that the measures used to indicate the trade policy are all correlated to each other. Therefore, the interpretation of results will be difficult thus, living the results open to different interpretation. They concluded that due to the fact that the models are uninformative the relation between openness and growth is an open discussion.

Kappel (2003) argued that the usage of the openness index as a binary variable, such as in Sach and Warner Model, is a major weakness because the notion of openness is different over time and among countries, and the percentage used to determine it is arbitrarily chosen. According to him, a cumulative index would be a better choice that the openness index.

Furthermore, many other studies regarding the exports policies have been and conflicting with each other. Some studies show that countries which have been under the influence of liberalization programs have improved their export performance (Helleiner, 1990; Dutta \& Ahmed, 1999). On the other hand, other studies have found evidence of poor link between trade liberalization and economic growth (Greenaway \& Sapsford, 1994; Jenkins, 1997). Moreover, while studying the imports policies, numerous studies confirm that there is a strong impact positive trade openness on import growth and the impact is mainly through sensitivity to price and income changes (Bertola \& Fiani, 1991). Santos - Paulino and Thirlwall (2004) concluded that the impact of liberalization varies in countries with high trade protection from those with low levels of protections. They argued that the positive effect of trade liberalization on import growth is greatest in industries that have high levels of protectionism during the pre-liberalization.

\section{Methodology and Data}

In this session is evaluated relation between the trade volume and economic growth rate in the Western Balkans 
countries. Many econometric models that study this effect exists. The choice of this models is based on the availability of data source since the model tries to estimate the openness effect in economic growth in the WB countries in transition and these countries suffer from data absences. Due to this implication data set used is from only three WB countries: Albania, Macedonia and Serbia.

\subsection{Estimated Model}

For the purpose to measure the relationship between trade openness and economic growth in Western Balkan countries in transition, is used a panel data multi regression model. In the model, the following variables are considered.

(i) Dependent variable is GDPGRt: The gross domestic product growth rate measured quarterly. This is the dependent variable.

(ii) The first independent variable is OPENt: The current trade openness measure by the current trade volume quarterly percentage changes.

(iii) The first independent variable is OPENt-1: The trade openness of the previous quarter measure by the trade volume quarterly percentage changes in the previous quarter.

The estimated equation is:

Equation 3

$G D P G R_{t}=\beta_{0}+\beta_{1} O P E N_{t}+\beta_{2} O P E N_{t-1}+u$

Where $\beta_{0}$ is the expected intercept when the other variable in the equation is equal to zero and $\beta_{1}$ and $\beta_{2}$ are respectively the slope of OPEN $\mathrm{t}_{\mathrm{t}}$ and OPEN $\mathrm{N}_{\mathrm{t}-1}$ that indicate how much 1 percent change in trade openness in the current quater and one quater before impact the growth rate of GDP. While $u$ represent the estimated error. The method used to estimate the model is panel least squares. In the model are included 108 observation and both GDP growth rate and trade volume percentage changes are measured quarterly from 2005 to 2013. It also has three cross-section which are Albania, Macedonia and Serbia. This analysis is conducted by Eview 7 software.

Table 1 show the results for the regression model and the estimated equation is:

Equation 4

GDPGR $_{t}=1.166+0.0630 \mathrm{PEN}_{t}+0.0380 P E N_{t-1}$

Accordingly, an increase in the trade activity of the countries has a positive relationship with the economic growth. Also, if everything else held fixed, 1 percentage change in trade volume in the current quarter will impact GDP growth rate by $0.063 \%$. This impact is higher than the impact that the trade volume change of the previous quarter will have on the GDP growth rate. However, this impact is $0.038 \%$, higher than the half of the current trade volume percentage change impact. Moreover, the $p$-values are less than 0.05 thus there is enough evidence to reject the null hypothesis which predicts that the independent variable are insignificant $\left(\beta_{1}\right.$ or $\beta_{2}$ are equal to zero).

Table 1: Estimated regression results of the model

\begin{tabular}{|c|c|c|c|c|}
\hline \multicolumn{5}{|c|}{$\begin{array}{l}\text { Dependent Variable: GDPGR } \\
\text { Method: Panel Least Squares } \\
\text { Date: 05/28/14 Time: 17:08 } \\
\text { Sample (adjusted): 2005Q2 2013Q4 } \\
\text { Periods included: } 35 \\
\text { Cross-sections included: } 3 \\
\text { Total panel (balanced) observations: } 105 \\
\end{array}$} \\
\hline Variable & Coefficient & Std. Error & t-Statistic & Prob. \\
\hline $\begin{array}{c}\text { C } \\
\text { OPEN (-1) } \\
\text { OPEN }\end{array}$ & $\begin{array}{l}1.166073 \\
0.037989 \\
0.063317\end{array}$ & $\begin{array}{l}0.255589 \\
0.017497 \\
0.019356\end{array}$ & $\begin{array}{l}4.562289 \\
2.171207 \\
3.271268\end{array}$ & $\begin{array}{l}0.0000 \\
0.0322 \\
0.0015\end{array}$ \\
\hline $\begin{array}{c}\text { R-squared } \\
\text { Adjusted R-squared } \\
\text { S.E. of regression } \\
\text { Sum squared resid } \\
\text { Log likelihood } \\
\text { F-statistic } \\
\text { Prob(F-statistic) }\end{array}$ & $\begin{array}{c}0.102075 \\
0.084469 \\
2.362192 \\
569.1549 \\
-237.7236 \\
5.797648 \\
0.004123 \\
\end{array}$ & $\begin{array}{l}\text { Mean d } \\
\text { S.D. de } \\
\text { Akaike } \\
\text { Schwa } \\
\text { Hannan } \\
\text { Durbin- }\end{array}$ & $\begin{array}{l}\text { lent var } \\
\text { ent var } \\
\text { riterion } \\
\text { terion } \\
\text { n criter. } \\
\text { on stat }\end{array}$ & $\begin{array}{l}1.537333 \\
2.468759 \\
4.585212 \\
4.661040 \\
4.615939 \\
1.194281\end{array}$ \\
\hline
\end{tabular}


Also table 2, shows the Wald Test for the null hypothesis that predict that all the independent variables included in the model are insignificant thus that both $\beta_{1}$ and $\beta_{2}$ are equal to zero. Accordingly, the $p$-value are lower than 0.05 , so there exists enough evidence to reject the null hypothesis. Thus, it can be concluded that all the independent variables are statistically significant in predicting the model.

Table 2: Walt Test for the independent variables significance in predicting the model

\begin{tabular}{|c|c|c|c|}
\hline $\begin{array}{l}\text { Wald Test: } \\
\text { Equation: Significance Te }\end{array}$ & & & \\
\hline Test Statistic & Value & $\overline{\mathrm{Dff}}$ & Probability \\
\hline F-statistic & 5.797648 & 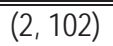 & 0.0041 \\
\hline Chi-square & 11.59530 & 2 & 0.0030 \\
\hline
\end{tabular}

Moreover, in order to check the stationary of data of the model, a panel unit root test was conducted and the results are shown in the table 3-5. Levin, Lin and Chin method assumes a common unit root process. On the other hand, Im, Peseran and Shin and Fisher Methods Type ADF and Type PP assumes individual unit root process. All the methods have a null hypothesis that predict a not-stationary series.

Table 3: Stationary Test for GDP growth rate data

\begin{tabular}{|c|c|c|c|c|}
\hline \multicolumn{5}{|c|}{$\begin{array}{l}\text { Series: GDPGR } \\
\text { Date: 05/28/14 Time: } 16: 56 \\
\text { Sample: 2005Q1 2013Q4 } \\
\text { Exogenous variables: Individual effects } \\
\text { User-specified maximum lags } \\
\text { Automatic lag length selection based on SIC: } 0 \\
\text { Newey-West automatic bandwidth selection and Bartlett kernel } \\
\text { Balanced observations for each test } \\
\end{array}$} \\
\hline Method & Statistic & Prob.** & Cross-sections & Obs \\
\hline \multicolumn{5}{|c|}{ Null: Unit root (assumes common unit root process) } \\
\hline Levin, Lin \& Chu t* & -6.88384 & 0.0000 & 3 & 105 \\
\hline \multicolumn{5}{|c|}{ Null: Unit root (assumes individual unit root process) } \\
\hline Im, Pesaran and Shin W-stat & -7.98368 & 0.0000 & 3 & 105 \\
\hline ADF - Fisher Chi-square & 60.8069 & 0.0000 & 3 & 105 \\
\hline PP - Fisher Chi-square & 61.9410 & 0.0000 & 3 & 105 \\
\hline
\end{tabular}

Table 3 and 4 show respectively the results of GDPGR and OPEN data for unit root tests. Accordingly, the probability level of the null hypothesis of all the four mentioned methods is equal to zero. Thus, there is enough evidence to reject the null hypothesis at the significance level $0.05 \%$ and conclude that the data does not have a unit root and is stationary at level. 
Table 4: Stationary Test for trade volume percentage change data

\begin{tabular}{|c|c|c|c|c|}
\hline \multicolumn{5}{|c|}{$\begin{array}{l}\text { Panel unit root test: Summary } \\
\text { Series: OPEN } \\
\text { Date: 05/28/14 Time: } 16: 59 \\
\text { Sample: 2005Q1 2013Q4 } \\
\text { Exogenous variables: Individual effects } \\
\text { User-specified maximum lags } \\
\text { Automatic lag length selection based on SIC: } 0 \\
\text { Newey-West automatic bandwidth selection and Bartlett kernel } \\
\text { Balanced observations for each test }\end{array}$} \\
\hline \multicolumn{5}{|c|}{ Null: Unit root (assumes common unit root process) } \\
\hline \multicolumn{5}{|c|}{ Null: Unit root (assumes individual unit root process) } \\
\hline Im, Pesaran and Shin W-stat & -16.3320 & 0.0000 & 3 & 105 \\
\hline ADF - Fisher Chi-square & 110.684 & 0.0000 & 3 & 105 \\
\hline PP - Fisher Chi-square & 87.0746 & 0.0000 & 3 & 105 \\
\hline
\end{tabular}

\subsection{Interpretation of the Results}

The results of the empirical analysis show that independent variables in the model which are current quarterly trade volume percentage change and previous quarterly percentage change are significant in determining the Gross Domestic Product growth rate in Albania, Macedonia and Serbia for the period 2005 to 2013.

The positive impact of trade openness in the economic growth signals a positive impact in the regions welfare such as income of the nation or the welfare of the populations. Thus, by increasing the volume of exports and imports, or in other words the total volume of trade as much as possible by using several way such as removing trade barrier, research and development methods, improving technology, increasing competition, etc., Western Balkans countries can increase its nation and per capita income.

The results are in coherence with the majority of theoretical approaches and literature reviewed in the study, which indicate that openness has a significant positive effect on economic growth of a country and/or region.

\section{Conclusions}

For many years, Western Balkans was the center of the conflict in Europe. During the last decade, it seems that these conflict has been put to a stop, and the Western Balkan countries are inspiring for further peaceful development and integration to European Union. The list of WB countries includes Republic of Albania together with all the countries of Former Republic of Yugoslavia except the Republic of Slovenia. After the collapse of communism regimes that ruled in the region, the countries started to open their trade and undertook for many years reforms to improve their economy, trade and trade balance. Of all these country, only Croatia is a member of European Union while the others are still in their respective journey of transition.

The link between trade openness and economic growth has been proven to be difficult in analyzing since they exist many studies that contradict each other regarding the positive or negative effect of trade openness on economic growth. However, the majority of this studies advocate positive impact of openness in economic growth.

Following, the result of the regression analysis conclude that 1 percent increase in the quarterly trade volume increases the current quarterly GDP growth rate by $0.062 \%$ in the current quarter and by $0.038 \%$ in the following one. However, in the regression analysis are included only 3 countries out of 6 Western Balkans countries in transition due to the absence of needed data. Yet, countries included in the regression analysis, which are Albania, Macedonia and Serbia, together represent the majority share of GDP among the Western Balkan Countries.

To sum up, the results of this paper emphasize the importance of trade openness for economic growth. It recommends that in order to improve the nation's welfare, Western Balkan should countries have as one of the primary objective the increase of their trade volume. This objective can be reach by increasing the competition, further lowering their trade barrier, increasing cooperation within and outside the region, emphasizing the importance of R\&D methods, 
improving technology, etc.

This research will enrich the topic of openness and economic growth as it is the first study conducted in the scope of Western Balkan. However, this study only examined the impact that trade openness had on economic growth, however, the hypothesis that there exist a significant or not significant positive or negative impact of economic growth rate of trade openness policies can be conducted. Also, both economic growth and trade openness are two complex indicators and should be considered carefully. Thus, future studies that also can be conducted are those that aim to determine main indicators of economic growth that have the highest impact of trade or are more highly impacted by trade openness or visa vie.

\section{References}

Bertola, G., \& Faini, R. (1990). Import demand and non-tariff barriers: The impact of trade liberalization : An application to Morocco. Journal of Development Economics, 34(1-2), 269-286.

Calhoun, C. (2002). Classical Sociological Theory. Wiley.

Charbit, Y. (2002). The Political Failure of an Economic Theory: Physiocracy. Population (english edition), 57(6), 855-884.

Corden, W. (1971, February). The theory of protection. Journal of International Economics, 2(1), 106-107.

Davis, W. L., Figgins, B. G., Hedengren, D., \& Klein, D. B. (2011). Economics Professors' Favorite Economic Thinkers, Journals, and Blogs (along with Party and Policy Views). Econ Journal Watch, 8(2), 126-146.

Dion, D.-P. (2004). "Trade, growth and geography: A synthetic. Discussion Paper Series of SFB/TR 15 Governance and the Efficiency of Economic Systems No. 22.

Dollar, D., \& Kraay, A. (2001). Trade, Growth, and Poverty. Policy Research Working Paper Series 2615.

Domar, E. (1946). Capital Expansion, Rate of Growth, and Employment. Econometrica, 14(2), 197-147.

Dutta, D., \& Ahmed, N. (1999). An aggregate import demand function for Bangladesh: a cointegration approach. Applied Economics, 31(4), 465-472.

Edwards, S. (1998, March). Openness, Productivity and Growth: What Do We Really Know? Economic Journal, 108(447).

Ekelund, R. B., \& Tollison, R. D. (1983). Mercantilism as a Rent-Seeking Society: Economic Regulation in Historical Perspective. The American Historical Review, 88(1), 81-83.

Greenaway, D., \& Sapsford, D. (1994). What does liberalisation do for exports and growth? Review of World Economics (Weltwirtschaftliches Archiv), 130(1), 152-174.

Harrod, R. (1939). An Essay in Dynamic Theory. The Economic Journal, 49(193), 14-33.

Helleiner, G. K. (1990). Trade strategy in medium-term adjustment. (Elsevier, Ed.) World Development, 18(6), 879-897.

Howard, M. C., \& King, J. E. (1989). A History of Marxian Economics. New Jersey: Princeton University Press.

Hsiao, F. S., \& Hsiao, M.-C. W. (2006, December). FDI, exports, and GDP in East and Southeast Asia--Panel data versus time-series causality analyses. Journal of Asian Economics, 17(6), 1082-1106.

Jenkins, R. (1997). Trade Liberalisation in Latin America: The Bolivian Case. Bulletin of Latin American Research, 16(3), $307-325$.

Kappel, R. (2003). Openness, Institutions, and Policies: Determinants of Globalisation and Economic Growth in Developing Countries. The Pakistan Development Review, 42(4), 395-416.

LaHaye, L. (2008). Mercantilism. Retrieved April 10, 2014, from Library of Economics and Liberty, The Concise Encyclopedia of Economics: http://en.wikipedia.org/wiki/Mercantilist\#cite_note-2

Lee, J.-W. (1993, June). International Trade Distortions and Longrun Economic Growth. Staff Paper, 40(2), $299-328$.

Malthus, T. R. (1978). An Essay on the Principle of Population (2008 ed.). (P. James, Ed.) Cambridge University Press.

Mankiw, N. G. (2006). Section 8.4 - Beyond the Solow Model: Endogeneus Growth Theory. In N. G. Mankiw, Macroeconomis (6 ed., pp. 235-236). Wh Freeman.

Bertola, G., \& Faini, R. (1990). Import demand and non-tariff barriers: The impact of trade liberalization : An application to Morocco. Journal of Development Economics, 34(1-2), 269-286.

Calhoun, C. (2002). Classical Sociological Theory. Wiley.

Charbit, Y. (2002). The Political Failure of an Economic Theory: Physiocracy. Population (english edition), 57(6), 855-884.

Corden, W. (1971, February). The theory of protection. Journal of International Economics, 2(1), 106-107.

Davis, W. L., Figgins, B. G., Hedengren, D., \& Klein, D. B. (2011). Economics Professors' Favorite Economic Thinkers, Journals, and Blogs (along with Party and Policy Views). Econ Journal Watch, 8(2), 126-146.

Dion, D.-P. (2004). "Trade, growth and geography: A synthetic. Discussion Paper Series of SFB/TR 15 Governance and the Efficiency of Economic Systems No. 22.

Dollar, D., \& Kraay, A. (2001). Trade, Growth, and Poverty. Policy Research Working Paper Series 2615.

Domar, E. (1946). Capital Expansion, Rate of Growth, and Employment. Econometrica, 14(2), 197-147.

Dutta, D., \& Ahmed, N. (1999). An aggregate import demand function for Bangladesh: a cointegration approach. Applied Economics, 31(4), 465-472.

Edwards, S. (1998, March). Openness, Productivity and Growth: What Do We Really Know? Economic Journal, 108(447).

Ekelund, R. B., \& Tollison, R. D. (1983). Mercantilism as a Rent-Seeking Society: Economic Regulation in Historical Perspective. The American Historical Review, 88(1), 81-83. 
Greenaway, D., \& Sapsford, D. (1994). What does liberalisation do for exports and growth? Review of World Economics (Weltwirtschaftliches Archiv), 130(1), 152-174.

Harrod, R. (1939). An Essay in Dynamic Theory. The Economic Journal, 49(193), 14-33.

Helleiner, G. K. (1990). Trade strategy in medium-term adjustment. (Elsevier, Ed.) World Development, 18(6), 879-897.

Howard, M. C., \& King, J. E. (1989). A History of Marxian Economics. New Jersey: Princeton University Press.

Hsiao, F. S., \& Hsiao, M.-C. W. (2006, December). FDI, exports, and GDP in East and Southeast Asia--Panel data versus time-series causality analyses. Journal of Asian Economics, 17(6), 1082-1106.

Jenkins, R. (1997). Trade Liberalisation in Latin America: The Bolivian Case. Bulletin of Latin American Research, 16(3), $307-325$.

Kappel, R. (2003). Openness, Institutions, and Policies: Determinants of Globalisation and Economic Growth in Developing Countries. The Pakistan Development Review, 42(4), 395-416.

LaHaye, L. (2008). Mercantilism. Retrieved April 10, 2014, from Library of Economics and Liberty, The Concise Encyclopedia of Economics: http://en.wikipedia.org/wiki/Mercantilist\#cite_note-2

Lee, J.-W. (1993, June). International Trade Distortions and Longrun Economic Growth. Staff Paper, 40(2), $299-328$.

Malthus, T. R. (1978). An Essay on the Principle of Population (2008 ed.). (P. James, Ed.) Cambridge University Press.

Mankiw, N. G. (2006). Section 8.4 - Beyond the Solow Model: Endogeneus Growth Theory. In N. G. Mankiw, Macroeconomis (6 ed., pp. 235-236). Wh Freeman.

Marx, K., \& Engels, F. (1998). Theories of Surplus Value. In K. Marx, \& F. Engels, Collected Works of Karl Marx and Friedrich Engels (pp. 355-358). New York: International Publishers.

Milionis, P. (2012). Long-Run Development in the Open Economy. DEGIT Conference Papers c017_059.

Raurich, X., \& Sorolla, V. (2012). Growth Models with Exogenous Saving Rates, Unemployment and Wage Inertia. Working Papers in Economics 287.

Ricardo, D. (1795). The Works and Correspondence of David Ricardo (Vols. 10 - Biographical Miscellany ). (M. H. Dobb, \& P. Sraffa, Eds.) Liberty Fund.

Ricardo, D. (1817). Chapter 6, On Profits. In D. Ricardo, \& 3. (1821) (Ed.), On The Principles of Political Economy and Taxation . London: John Murray .

Roberts, P. C. (2003, August 27). The trade question. Retrieved April 2014, 24, from Washington Times: http://www.washingtontimes. com/news/2003/aug/27/20030827-084257-6403r/?page=all

Rodríguez, F. R., \& Rodrick, D. (2001). Trade Policy and Economic Growth: A Sceptic's Guide to the Cross-National Evidence. NBER chapters in NBER Macroeconomics Annual 2000, 15, 261-338.

Rodrik, D. (1995). Trade Strategy, Investment and Exports: Another Look at East Asia. CEPR Discussion Papers 1305.

Romer, P. (1994). The Origins of Endogenous Growth. The Journal of Economic Perspectives, 8(1), 3-22.

Sachs, J. D., \& Warner, A. M. (1995). Natural Resource Abundance and Economic Growth. Cambridge: National Bureau of Economic Research, Inc.

Samuelson, P. A., \& Nordhaus, W. D. (2001). Microeconomics (17 ed.). McGraw-Hill.

Santos-Paulino, A., \& Thirlwall, A. P. (2004). The impact of trade liberalisation on exports, imports and the balance of payments of developing countries. Economic Journal, 114(493), F50-F72.

Smith, A. (1779). An Inquiry into the Nature and Causes of the Wealth of Nations (5 (1904) ed.). (E. Cannan, Ed.) London: Methuen \& Co., Ltd.

Solow, R. M. (1956). A Contribution to the Theory of Economic Growth. The Quarterly Journal of Economics, 70(1), 65-94.

Solow, R. M. (1957). Technical Change and the Aggregate Production Function. The Review of Economics and Statistics, 39(3), 312320.

Swan, T. W. (1956). Economic Growth and Capital Accumulation. Economic Record, 32(2), 334-361.

Winch, D. (1996). Riches and Poverty: An Intellectual History of Political Economy in Britain, 1750-1834. Cambridge University Press. 